\title{
Reconstruction of Legal Protection of Debtors in the Execution of Mortgage Guarantee Object Based on the Value of Pancasila Justice
}

\author{
Budi Supriyatno $^{1 *}$, Gunarto ${ }^{2}$, Amin Purnawan ${ }^{3}$, Hesti Kristi Wahyudi ${ }^{4}$, Rais Firdaus Handoko ${ }^{5}$ \\ ${ }^{1}$ Doctorate Student of Faculty of Law Sultan Agung Islamic University Semarang, Indonesia \\ ${ }^{2}, 3$ Faculty of Law Sultan Agung Islamic University Semarang, Indonesia \\ ${ }^{4}$ Master Student of Faculty of Law Sultan Agung Islamic University Semarang, Indonesia \\ ${ }^{5}$ Master of Notary Student of Faculty of Law Sultan Agung Islamic University Semarang, Indonesia
}

DOI: $10.36348 /$ sijlcj.2021.v04i01.002 $\quad$ | Received: 14.01.2021 | Accepted: 25.01.2021 | Published: 29.01 .2021

*Corresponding author: Budi Supriyatno

\section{Abstract}

The implementation of legal protection for debtors in the execution of the mortgage guarantee object in Indonesia is currently not able to realize justice, therefore it is necessary to conduct research to examine what its weaknesses are and how to reconstruct legal protection for debtors in executing the object of guarantee of mortgage rights based on Pancasila justice. The research method used in this article is a non-doctrinal method with a constructivist paradigm. Based on the research conducted, it was found that the execution of the object of the guarantee of mortgage is not yet fair, this is because the Parate execution as intended in Article 6 of the UUHT has resulted in loopholes for the occurrence of misuse of the situation by the creditor to the debtor which will ultimately harm the debtor which resulted from the weakness of the execution of the object of guarantee of mortgage rights in Indonesia currently is in the implementing regulations of Article 6 of the UUHT using implementing regulations in the form of Minister of Finance Regulation Number 27 / PMK.06 / 2016 which is not recognized in the UUHT and also contradicts the terms of execution according to HIR. in order to solve this, a reconstruction of law is needed in the form of a regulation which oblige them before conducting the auction, to transform the property rights in to collateral property.

Keywords: Reconstruction, Debtor, Mortgage Execution, Pancasila Justice.

Copyright ( $) 2021$ The Author(s): This is an open-access article distributed under the terms of the Creative Commons Attribution 4.0 International License (CC BY-NC 4.0) which permits unrestricted use, distribution, and reproduction in any medium for non-commercial use provided the original author and source are credited.

\section{INTRODUCTION}

In order to guarantee legal certainty and justice in the capital law sector in Indonesia, Law Number 4 of 1996 concerning Land Mortgage Rights and Landrelated Objects was drafted. Law No. 4 of 1996 concerning Mortgage Rights to Land and Land-related Objects was formed with the spirit of supporting the realization of national economic development through the capital funding sector. So it is clear that Law Number 4 of 1996 concerning Mortgage Rights to Land and Objects Related to Land should maintain a balance between debtors and creditors in terms of guaranteeing rights and obligations in the world of capital and guarantees that are just and balanced in order to realize progress of the business world and the industrial world in order to sustain national economic progress.

In contrast to the expectations described above, the practice of guaranteeing mortgage rights is often not in line with this spirit. One of the proofs of this is the execution of the object of the guarantee of the mortgage which is based only on Article 6 of Law Number 4 of 1996 concerning Mortgage Rights to Land and Objects related to land. Article 6 of Law Number 4 of 1996 concerning Mortgage Rights on Land and Objects Related to Land clearly states that the creditor as the holder of the first mortgage has the right to sell the object of the Mortgage on his own power through a public auction and to collect his receivables from proceeds from the sale when the debtor breaches his promise. Basically, the meaning of the debtor's default in these provisions means the debtor does not pay the installments that are due. However, this is clearly not completely true considering that not all debtors who do not pay installments are due to lack of good etiquette, given that there is one thing, for example, the Covid-19 pandemic [1] that reduces their income and increases spending so that temporarily they are unable to pay installments to creditors, can also be the cause of not paying the debtor to the creditor (or commonly known as force majeure). 
The problem as above arises because the execution of the object of mortgage in Indonesia based only on the Minister of Finance Regulation Number 27 of 2016 concerning Technical Appointments for Auction Implementation is not entirely correct, this is considering in Article 26 and the explanation in Law Number 4 of 1996 Regarding Mortgage Rights to Land and Objects related to land, there is no mention of implementing regulations for the execution of the existing mortgage guarantee objects. So that the Regulation of the Minister of Finance Number 27 of 2016 concerning Technical Appointments for the Implementation of Tenders is not included in the implementing regulations which in this case carry out the technicalities of Article 6 and Article 14 of Law Number 4 of 1996 concerning Mortgage Rights to Land and Objects Related to Land. Additionally, according to Article 7 of Law Number 12 of 2011 concerning the Establishment of Legislation, the implementation of Article 6 and Article 14 of Law Number 4 of 1996 concerning Mortgage Rights to Land and Land-related Objects should be more based on Herzien Inlandsch Reglement (HIR) and the provisions of Minister of Finance Regulation Number 27 of 2016 concerning Technical Appointments for Auction Implementation cannot contradict HIR. Given the position of the Minister of Finance Regulation Number 27 of 2016 concerning Technical Appointments for Auction Implementation is not clear and if you look at Article 7 of Law Number 12 of 2011 concerning the Formation of Legislation, the position of Regulation of the Minister of Finance Number 27 of 2016 concerning Technical Appointments for the Implementation of Tenders is at under HIR.

Based on the various kinds of explanations above, it is clear that the arrangement of the mortgage right execution mechanism has so far resulted in injustice for both the debtor and the auction buyer of the object of the mortgage which was parate executed [2]. This has clearly hampered economic growth, resulting in the violation of the First, Second, and Fifth Precepts of Pancasila, the Fourth Paragraph of the 1945 Constitution of the Republic of Indonesia, and Article 2 of Law Number 8 of 1999 concerning Consumer Protection, This also violates the provisions related to the validity of the agreement on the basis of lawful and clear objectives as stipulated in Article 1320 of the Civil Code. This is shown by the lawsuit against Article 14 and Article 20 of Law Number 4 of 1996 concerning Mortgage Rights to Land and Objects Related to Land in the Constitutional Court as these articles, especially insofar as the phrase 'executorial power' and the phrase 'are the same as a court decision that has obtained permanent legal force, and the phrase' breach of promise 'has created injustice and legal uncertainty for the debtor, thus contradicting the 1945 Constitution., in particular Article 1 paragraph (3), Article 27 paragraph (1), Article 28D paragraph 8 (1), Article 28G paragraph
(1) and Article 28H paragraph (4) of the 1945 Constitution.

This problem is what urges the author to study it further in a research with the following issues:

1. What are the weaknesses that arise in the implementation of legal protection for debtors in the execution of the object of guarantee of mortgage in Indonesia currently?

2. How is the reconstruction of legal protection for debtors in the execution of the object of guarantee of mortgage in Indonesia based on the value of Pancasila justice?

\section{METHOD OF RESEARCH}

The paradigm that is used in the research this is the paradigm of constructivism which is the antithesis of the understanding that lay observation and objectivity in finding a reality or science knowledge [3]. Paradigm also looked at the science of social as an analysis of systematic against Socially Meaningful Action through observation directly and in detail to the problem analyzed.

The research type used in writing this paper is a qualitative research. Writing aims to provide a description of a society or a certain group of people or a description of a symptom or between two or more symptoms.

Approach method used in this research is Empirical-Juridical [4], which is based on the norms of law and the theory of the existing legal enforceability of a law viewpoint as interpretation.

As for the source of research used in this study are:

1. Primary Data is data obtained from information and information from respondents directly obtained through interviews and literature studies.

2. Secondary Data is an indirect source that is able to provide additional and reinforcement of research data. Sources of secondary data in the form of: Primary Legal Material and Secondary Legal Materials and Tertiary Legal Material.

In this study, the author use data collection techniques, namely literature study, interviews and documentation where the researcher is a key instrument that is the researcher himself who plans, collects, and interprets the data [5]. Qualitative data analysis is the process of searching for, and systematically compiling data obtained from interviews, field notes and documentation by organizing data into categories, describing it into units, synthesizing, compiling into patterns, selecting important names and what will be studied and make conclusions. 
RESEARCH RESULT AND DISCUSSION

1. Weaknesses That Arise In The Implementation Of Legal Protection For Debtors In The Execution of The Object Of Guarantee Of Mortgage In Indonesia Currently

The fatal weakness of the Implementation of Legal Protection Against Debtors in the Execution of Guarantee Objects of Mortgage Rights in Indonesia Currently lies in the aspects of the provisions of Article 6 and Article 20 of the Mortgage Law which are further supported by Article 1178 paragraph (2) of the Civil Code which has resulted in loopholes for abuse of circumstances (misbruik van omstandigheden) by the creditor against the debtor in the case of the implementation of the agreement related to the execution of the collateral object.

In the common law system which is implemented in Indonesia, in addition to undue influence, there is also unconscionability, both of which are different, although they have similarities, namely that both are based on an imbalance in the bargaining position of the parties. If a contract is formed on the basis of impropriety or injustice that occurs in an unbalanced relationship between the parties, then this is called undue influence, but if injustice occurs because of a situation (in which are not the result of the will of the parties), is called unconscionability. In the decision of the Commercial Bank of Australia v Amadio 151 CLR 447, Rusli [6] stated that the undue influence doctrine was seen as a consequence of this imbalance on the granting of agreements from the affected party, while unconscionability was seen from the behavior of powerful parties in their efforts to force or take advantage of the transaction against weak people, whether it is in accordance with propriety.

Then in the case of undue influence, there must be some form of exploitation by one of the parties over the weaker party. A party trying to cancel a transaction on the basis of undue influence must prove that the transaction is dishonest, that the innocent party has been harmed. The other party must protect itself by proving that professional and independent advice has been given before the transaction is concluded.

In his development, Panggabean [7] always linked his discussions with the arresters found in the Netherlands. The inclusion of the provisions on the abuse of circumstances in the NBW is to some extent the background of legal considerations in various judges' decisions.

The formation of teachings about the abuse of circumstances was due to the absence of (at that time) the Burgerlijk Wetboek (Netherlands) provisions regulating it. In the event that a judge finds a situation contrary to custom, it is often found that the judge's decision cancels the agreement in whole or in part. It turns out that the judges' considerations were not based on one of the reasons for the cancellation of the agreement, namely the classic defect will (article 1321 of the Civil Code) in the form of:

1. Digression (dwaling);

2. Coercion (dwang);

3. Fraud (bedrog) (article 1321 of the Civil Code).

When looking at the various mortgages guarantee agreements between creditors and debtors, most of the agreements made by creditors only benefit the creditor. This can be seen with most guarantees of mortgage agreements when regulating the provisions related to the execution of objects of collateral right of guarantee only looking at the provisions of Article 6 and Article 20 of the Mortgage Law and Regulation of the Minister of Finance No. 27 / PMK.06 / 2016 concerning the Instructions for Conducting Tenders only is not balanced with the existence of a proof system in the form of a financial audit prior to the debtor, even though this is contrary to the explanation of Article 26 Mortgage Law and Article 224 HIR. This has clearly resulted in digression and coercion and even fraud in relation to the execution of collateral objects as evidenced by the debtor's powerlessness and lack of bargaining power as well as a fair and balanced bargaining mechanism between the debtor and creditor.

This is indicated by the guarantee agreement of the mortgage rights which from the beginning was determined unilaterally by the creditor, not jointly negotiated with the debtor, so that when there is an arrears, the debtor is immediately deemed invalid without being given room to prove the reason for the arrears through fair negotiations, this is clearly included in digression then It can even be categorized as fraud, because the information about the agreement made by the creditor is not fully understood, and usually the creditors are persuaded with the promise of fast disbursement of funds if the guarantee agreement is signed quickly without providing detailed information regarding the contents of the guarantee of rights agreement. Dependents that will be signed by the debtor. This clearly includes deception and fraud which falls under the category of the abuse of situation.

Then the implementation of the parate execution without considering the examination and audit of the correctness of the debtor's condition with defects in promise and without the approval of the debtor due to the existence of Article 6 Mortgage Law and Article 20 Mortgage Law and Regulation of the Minister of Finance No. which can be categorized as misbruik van omstandigheden or undue influence or the abuse of circumstances. At first, this situation is clearly not fair to the debtor.

This can be seen in the case of Sulasmi's case [8], a case occurred when Sulasmi's land of $712 \mathrm{~m} 2$ located in Gondangmanis Village, Bae District, Kudus Regency was made the object of collateral for the Bank 
Rakyat Indonesia (BRI) of Kudus City Branch in 2010. Then in its development, Sulasmi has a debt of Rp. $150,000,000.00$ to BRI was unable to pay its debt to creditors and requested an extension of the loan amounting to Rp. 200,000,000.00. The creditors who saw the condition of Sulasmi, who is 52 years old and currently suffering from a cancer, should not agree with this, considering that Sulasmi is in an impossible condition to pay off her debts. In fact, BRI approved the application by adding the area of land plots used as collateral for mortgages without being registered with a certificate of mortgage, only an authentic deed was made before a notary public and PPAT with the number of accounts receivable extension No. 27. In its recent development, it was discovered that there was another problem, namely regarding the number of mortgage rights stated in the certificate of mortgage number 3302 with the number of mortgage rights in the minutes of auction. In the mortgage certificate number 3302, the number of objects of mortgage is three fields, while in the minutes of auction there are five fields that are guaranteed mortgage. This was later found to be due to the collateral object in the deed No. 27 is not registered in the mortgage certificate, only made before a Notary Public and PPAT. This matter got even more complicated after Sulasmi passed away. After her death, Sulasmi's debt which was never known by her heir, Tities Sriyani, BRI continued his payment obligations to Tities Sriyani and in 2010 the debt was repaid by Tities Sriyani, but after economic difficulties in 2011, Tities Sriyani did not manage to continue the installment and in the end BRI carried out the execution of the land and house belonging to Sulasmi which was inherited by Tities Sriyani, on a parate basis which is not through an aanmaning procedure. This is clearly unfair considering that from the beginning BRI Kudus made its receivables policy not based on the condition and position of the debtor, which in the end was the heir of the debtor who did not know and understand the contents of the agreement between BRI and Sulasmi had to bear losses without being able to defend them. This situation is called the abuse of the situation. This happens due to the absence of an institution and system of supervision of the running of Article 6 of the Mortgage Law.

\section{Reconstruction of Legal Protection for Debtors in the Execution of the Object of Guarantee of Mortgage in Indonesia Based On the Value of Pancasila Justice}

In order to realize the various ideas above it is necessary to carry out legal reconstruction, as for the legal reconstruction in the issue of debtor protection related to the execution of guarantee rights, it is necessary to amend the provisions of Article 6 of Law Number 4 of 1996 concerning Mortgage Rights, as for the changes made to include an obligation that Parate execution must be with the knowledge of the debtor and beforehand there needs to be a test or audit regarding the correctness of the element of a defect before executing through an audit conducted by an appraisal party which is neutral and has no close relationship with the creditor or debtor. Then before carrying out the auction, it is necessary to transfer the property rights to the object of collateral, namely by the first step of making an application for an execution to the court to be cleared and clear and clean of the object of the guarantee of the mortgage so that when the object of the guarantee is carried out, the object of the guarantee is not experiencing problems as regulated in Supreme Court circular letter (Sema) MA No. 4 of 2014 concerning the Enforcement of the Formulation of Results of the 2013 Plenary Meeting of the Supreme Court Chamber as Guidelines for the Implementation of Duties for the Court, which states that: "With respect to the auction of mortgage rights by the creditor himself through the auction office, if the auctioneer does not want to vacate the auction object, the execution of blanking can be submitted directly to the Head of the District Court without going through a lawsuit".

It is clear that prior to the auction, the object should be requested to be executed in court so that the object of guarantee of mortgage after the auction is carried out can be processed, considering that the basis for roya (removal of deed status as a guarantee) is a certificate of ownership which is clearly not the minutes of the auction. Apart from that, executions also need to remember that there is a juridical handover requirement in every transfer of rights to objects of objects of collateral as provided for in Article 620 of the Civil Code which reads: "With regard to the provisions contained in the previous three articles, the announcement referred to above is made by transferring a complete authentic copy of the deed or the Judge's decision to the mortgage deposit office in the neighborhood where the immovable property to be delivered is located, and by registering This copy is in a predefined list. Together with that, the person concerned must also submit a second authentic copy or an excerpt from the deed or judge's decision, so that the mortgage depositor records in it the day of transfer along with the part and number of the relevant register".

The procedure for the transfer of rights to objects which become the object of this guarantee is also regulated in Government Regulation Number 24 of 1997 to be precise in Article 37 paragraph (1) which reads: "Transfer of rights to land and property rights to apartment units through sale and purchase, exchange, grant, entry into a company and other legal acts of transfer of rights (except the transfer of rights through auction) can only be registered if it is proven by a deed made by the competent PPAT according to the provisions of the prevailing laws and regulations".

It is further stated in Article 38 of Government Regulation Number 24 of 1997 that the making of deeds as referred to in Article 37 paragraph (1) is attended by the parties who have committed the legal 
act concerned and witnessed by at least 2 (two) witnesses who meet the requirements. to act as a witness in the legal act and the form, content and method of drawing up Land Titles Registrar (PPAT) deeds shall be regulated by the Minister.

The provisions of Article 37 of Government Regulation Number 24 of 1997 state that there must be a juridical handover in every land sale and purchase in order to stipulate clear land rights. Meanwhile, Article 38 of Government Regulation No. 24/1997 requires clear requirements in terms of making land rights. In the absence of a juridical handover of property rights over the object which is the object of guarantee by the debtor to the creditor, the conditions for jurisdiction levering cannot be realized so that this will also result in the inability of the creditor to roya the object of collateral after being auctioned if it is done without preceded by the execution of the court beforehand. So that this judicial friction in the execution of collateral rights objects need to be emphasized further in the Mortgage Law.

Based on the foregoing, the legal reconstruction in the case of debtor protection related to the execution of guarantee rights can be carried out by amending the provisions of Article 6 of Law Number 4 of 1996 concerning Mortgage Rights, as for the changes made to include an obligation that parate execution must be with the knowledge of the debtor and beforehand it is necessary to have a test or audit related to the correctness of the defect of promise before executing it through an audit conducted by a public accountant who is neutral and has no close relationship with creditors or debtors. So that it is necessary to carry out reconstruction in Article 6 of Law Number 4 Year 1996 concerning Mortgage Rights which initially reads: "If the debtor is in default, then the first Mortgage holder has the right to sell the object of the Mortgage on his own power through a public auction and collect his debt from proceeds from the sale ", becomes:

1. If the debtor is in default, then the holder of the first Mortgage has the right to sell the object of the Mortgage on his own power through a public auction and to collect his/her receivables from the sale proceeds.

2. Prior to carrying out the execution as referred to in paragraph (1), the creditor is obliged to conduct examination and evidence related to a defect made by the debtor.

3. The provisions referred to in paragraph (2) shall be carried out through an audit conducted by a certified public accountant which is neutral in nature.

4. Implementation of the execution as referred to in paragraph (1) must be clearly informed to the debtor in advance.

5. The implementation as meant in paragraph (1) shall be based on the highest price of the seller of the object of guarantee of mortgage.
Then, it is also necessary to add new Article (Article 6A) which states that:

1. Prior to the auction, the creditor must submit a request for execution to the district court at the location where the object of execution is located

2. After submitting the application by the creditor as referred to in paragraph (1), the Chairman of the District Court is obliged to summon the creditor and debtor to conduct a quick examination in the event that there has been a violation of the provisions of Article 6 of Law Number 4 Year 1996.

3. The examination conducted is related to the audit results and other supporting facts found by the public accountant regarding the existence of a promise defect by the debtor.

\section{Then also added Article $6 \mathrm{~B}$ which states that}

1. After a quick examination is carried out related to a defect in contract by the debtor, within 14 days the Head of the District Court is obliged to issue an order of execution if the debtor is proven to have failed his contract to the creditor.

2. If it turns out that the debtor is still able to fulfill his contract to the creditor, the Chairman of the District Court must reject the request for execution submitted by the creditor.

The above reconstruction, according to the author, can run well if the "value" of the reconstructed article also changes so that the community is willing to comply with it. This can be realized by adhering to the viewpoint of the value of Pancasila justice, that if the debtor is an individual and the case is not complicated, the German Accounts Receivable Law for example, provides special provisions at low cost in settling debtors' debts [9]. This mechanism is carried out in three steps. First, the debtor must endeavor to negotiate his debts with his creditors outside the court by submitting a peace plan. Second, if the first thing fails, then the debtor must file a bankruptcy application accompanied by a peace plan within six months. The court will present the peace plan to creditors to obtain a response from creditors. Third, if the second step fails, the next step is the mechanism for requesting a bankruptcy statement. In this process there is only a verification meeting process. An application for a bankruptcy statement submitted by an individual debtor includes an application for debt relief. This is a debate because they have to compromise between the difficulties experienced by the debtor on the one hand, and on the other hand, there is the principle of the binding strength of the contract or pacta sunt servanda (Contract, once sealed must be executed in good faith), that the debtor will only be given debt relief seven years after the debtor has made serious efforts to repay the debt. - owes to its creditors. In France, for example [10], where the gradual evolution of the bankruptcy law has accepted debt relief as the debt problem of individual debtors has increased. France allows after one year, but on the condition that the debtor can prove 
that "the compromise offered cannot be considered" and it does not appear that he has a chance to pay his debt in the future.

\section{CONCLUSION}

1. The Weaknesses in executing the object of guarantee of mortgage rights in Indonesia currently are its legal regulations, namely the implementation of Article 6 of the Mortgage Law (UUHT) which uses an implementing regulation in the form of Minister of Finance Regulation Number 27 / PMK.06 / 2016 which is not recognized in the UUHT and also contradicts the terms of execution according to HIR. Then the weakness of the execution of the object of guarantee of mortgage which is unable to provide legal certainty to the auction winner is because the auction results of the object of guarantee of mortgage only provide minutes of auction and not land ownership certificate which has its ownership status changed. In addition, there is no supervision regarding the execution of the object of the guarantee of mortgage which makes it prone to abuse of power.

2. Legal reconstruction in the issue of debtor protection related to the execution of guarantees of security rights is needed and it can be carried out by changing the provisions of Article 6 of Law Number 4 of 1996 concerning Mortgage Rights, as for the changes made to include an obligation that parate execution must be with the knowledge of the debtor and it is necessary beforehand. tests or audits related to the truth of the existence of an element of defect of promise prior to execution through an audit conducted by a public accountant who is neutral and has no closeness with creditors or debtors.

\section{REFERENCES}

1. Astuti, P. B., \& Mahardhika, A. S. (2020). COVID-19: How does it impact to the Indonesian economy?. Jurnal Inovasi Ekonomi, 5(02).

2. Poesoko, H. (2006). Parate executie obyek hak tanggungan (Doctoral dissertation, UNIVERSITAS AIRLANGGA).

3. Faisal. (2010). Menerobos Positivisme Hukum, Rangkang Education, Yogyakarta.

4. Ibrahim, J. (2005). Teori dan metode penelitian hukum normatif. Malang: Bayumedia Publishing.

5. Moleong, L. J. (2002). Metode penelitian kualitatif (Rev. ed.). Bandung: PT. Remaja Rosdakarya.

6. Rusli, H. (1993). Hukum Perjanjian Indonesia dan Common Law. Pustaka Sinar Harapan.

7. Henry, P. Panggabean. (1991). Penyalahgunaan Keadaan (Misbruik van Omstandigheden) Sebagai Alasan (Baru) Untuk Pembatalan Perjanjian (Berbagai Perkembangan Hukum Di Belanda), Liberty, Jogyakarta.

8. Tities, S. (2020). Interview, Tities in her position as Debtor (sulasmi) Heir Who is Aggrieved by BRI's Policy Regarding the Execution of Mortgage Collateral Objects in Kudus Regency on 12 September.

9. Van, vliet, Lars. (2009). Mortgages on Immovables in Dutch Law in Comparison to the German Mortgage and Land Charge. SSRN Electronic Journal. 10.2139/ssrn.1147543.

10. Widodo, W., Budoyo, S., \& Pratama, T. G. W. (2018). The role of law politics on creating good governance and clean governance for a freecorruption Indonesia in 2030. The Social Sciences, 13(8), 1307-1311. 